\section{Géneros}

Multidisciplinary Journal of Gender: Studies

\section{Hipatia Press \\ www.hipatiapress.com}

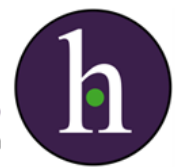

Instructions for authors, subscriptions and further details:

$\underline{\text { http://generos.hipatiapress.com }}$

\title{
"I Find that What I Do Is at Total Odds..." \\ Holistic Wellness in a Woman Leader Working in a Male- dominated Engineering Profession
}

Claude-Hélène Mayer ${ }^{1}$

1) Department of Management, Rhodes University, Grahamstown, South Africa.

Date of publication: October $25^{\text {th }}, 2016$

Edition period: October - February 2017

To cite this article: Mayer, C. (2016). "I Find that What I Do Is at Total Odds..." Holistic Wellness in a Woman Leader Working in a MaleDominated Engineering Profession. Multidisciplinary Journal of Gender Studies, 5(3), 1098-1125. doi: 10.17583/generos.2016.1806

To link this article: http://dx.doi.org/10.17583/generos.2016.1806

\section{PLEASE SCROLL DOWN FOR ARTICLE}

The terms and conditions of use are related to the Open Journal System and to Creative Commons Attribution License (CC-BY). 


\title{
"I Find that What I Do Is at Total Odds..."
}

Holistic Wellness in a Woman Leader Working in a Maledominated Engineering Profession

\author{
Claude-Hélène Mayer \\ Rhodes University
}

\section{Abstract}

To explore holistic wellness in depth, single, longitudinal case studies are needed. This article explores the holistic wellness of a woman leader in the male-dominated profession of Engineering, based on the holistic wellness model (HWM). It focuses on the question of how holistic wellness is constructed by this extraordinary individual working in the challenging Australian Engineering field.

The study is grounded in Dilthey's modern hermeneutics and applies a single case study design, using an in-depth interview, conversations on a regular basis and observation over a period of 18 months.

Findings show that this woman leader, working in the male-dominated, global Australian Engineering profession, builds her holistic wellness on life tasks (work and leisure, self-direction, spirituality, friendship and love) and life forces (family, religion, community and business and industry) which are part of the holistic wellness model. Life tasks and life forces support her as she tackles challenges in life, and provide her with the coping mechanisms she needs, as a woman leader in Engineering.

Keywords: holistic wellness model, woman leader, male-dominated profession, Engineering, Australia, Dilthey's modern hermeneutics 


\section{"Me Parece que lo que Hago Es por Probabilidad Total..." Holística del Bienestar en una Mujer Líder que Trabaja en una Profesión de Ingeniería Dominada por Los Hombres}

Claude-Hélène Mayer

Rhodes University

\section{Resumen}

Para explorar la holística del bienestar en profundidad, son necesarios estudios de caso longitudinales individuales. Este artículo explora la holística del bienestar de una mujer líder en la profesión dominada por los hombres de Ingeniería, basado en el modelo holístico del bienestar (HWM). Se centra en la cuestión de cómo la salud holística se construye mediante esta extraordinaria persona que trabaja en el campo desafiante de la Ingeniería en Australia.

El estudio se basa en la hermenéutica moderna de Dilthey y se aplica un sólo diseño de estudio de caso, utilizando una entrevista en profundidad, conversaciones regulares y la observación durante un período de 18 meses. Los resultados muestran que esta mujer líder, que trabaja en la profesión de la ingeniería australiana mundial dominada por los hombres, construye su bienestar integral en tareas de la vida (trabajo y ocio, autodirección, espiritualidad, amistad y amor) y fuerzas vitales (familia, religión, comunidad y los negocios y la industria), que son parte del modelo de bienestar integral. Tareas de la vida y las fuerzas vitales la apoyan mientras se fuerza a retos en la vida, y la dotan de los mecanismos de adaptación que necesita como una mujer líder en Ingeniería.

Palabras clave: modelo holístico de bienestar, mujer líder, profesión dominada por hombres, ingeniería, Australia, hermenéutica moderna de Dilthey 
W ellness is defined as a continuous movement to optimal functioning which is connected to self-responsibility and motivation (Roscoe, 2009). Myers (2009) points out that the holistic approach in wellness research includes the integration of physical, psychological and spiritual aspects and thereby focuses on the body, mind and spirit connection. Research on holistic wellness from a positive psychology perspective has generally gained interest since the 1950s (Coetzee \& Viviers, 2007; Roscoe, 2009; Strümpfer, 2005) and has become a field of research in organisational psychology, leadership and management research (Mayer 2011; Mayer \& Van Zyl, 2013).

Leadership research has recently started to explore the role of women leaders in global leadership contexts (Bangilhoe \& White, 2011; Carli \& Eagly, 1999; Gouws, 2008). Particular interest is shown in the progress of women leaders in senior management positions in male-dominated professions (Eagly, 2007; Martin \& Barnard, 2013). Research shows that Engineering is one of the most male-dominated professions globally. This is particularly true of the Engineering field in Australia (Sharp, Franzway, Mills \& Gill, 2012). Women working in male-dominated professions are particularly challenged (Kinnear, 2014, Rudman \& Phelan, 2010; Sandberg, 2013, Toh \& Leonardelli, 2012) by, for example, discriminatory practices or gender role stereotype behaviour (Du Plessis \& Barkhuozen, 2012). It has been emphasised that this situation impacts on women's resilience (Martin \& Barnard, 2013; Van Wyk, 2012). However, the question remains open: How do women leaders working in the Engineering profession stay well, whilst dealing with the complex challenges inherent to the profession?

\section{Holistic Wellness}

Wellness is a positive psychology construct that has been researched interdisciplinarily with a holistic and integrative focus (Myers, 2009). Myers, Sweeney and Witmer (2000) define wellness as a:

way of life orientation toward optimal health and wellbeing in which body, mind, and spirit are integrated by the individual to live more fully within the human and natural community. Ideally, it is the optimum state of health and wellbeing that each individual is capable of achieving. 
The holistic wellness model (HWM) refers to the wholeness of individuals who belong to a dynamic socio-cultural context, and highlights life tasks, life forces and global events (Witmer, 2000).

\section{Life tasks, life forces and global events}

The HWM is based on five life tasks. These tasks include spirituality; selfdirection (which consists of 12 sub-tasks, namely sense of worth; sense of control; realistic beliefs; emotional awareness and coping; problem solving and creativity; sense of humor; exercise; nutrition; self-care; stress management; gender identity; and cultural identity) (Myers \& Sweeney, 2007); work and leisure; and friendship and love (Myers, Sweeney \& Witmer, 2000). These life tasks interact dynamically with the life forces (defined as external influences), such as family, religion, education, community, government, media, and business/industry. Finally, global events such as disease, war, pollution, economic exploitation and/or poverty, are viewed as impacting on holistic wellness (Sweeney \& Witmer, 1991; Witmer \& Sweeney, 1992, 1998). All components are seen as being interactive, interdependent and systemically connected. In the following section, brief definitions for an overview are provided. ${ }^{1}$

Witmer and Sweeney (1992) define spirituality as "certain life-enhancing beliefs about human dignity, human rights, and reverence for life." Spirituality is a health resource (Mayer, 2011; Mayer \& Krause, 2013; Temane \& Wissing, 2006) that creates meaningfulness in life (Mayer \& Viviers, 2014) and can relate to the relationship with God.

Self-direction refers to the manner in which a person defines, regulates, manages and controls him/herself to achieve goals (Myers et al., 2000). It also relates to how social boundaries are constructed (Witmer \& Sweeney, 1992). The twelve sub-tasks of self-direction include the following subcategories (Myers \& Sweeney, 2008): (a) sense of worth, (b) sense of control, (c) realistic beliefs, (d) emotional awareness and coping, (e) problem-solving and creativity, (f) sense of humour, (g) nutrition, (h) exercise, (i) self-care, (j) stress management, (k) gender identity, and (l) cultural identity.

Both work and leisure include meaningful activities for the individual 
and are defined as pleasurable intrinsic experiences (Myers et al., 2000). Leisure impacts on the reduction of stress (Myers et al., 2000) and includes physical activities, creative work, and social engagements. These all have a positive effect on emotional wellbeing and wellness (Witmer \& Sweeney, 1992; Myers \& Sweeney, 2008).

Friendship includes both, social interaction and social connectedness on individual, communal or collective levels, but excludes "marital, sexual or familial commitment". Friendship is expressed through support systems, positive human interaction and constructive communication.

Finally, love refers to relationships which are built on intimate and cooperative relationships, long-term commitment, and self-disclosure. Love includes sexual relations and is viewed as a committed, lasting, intimate relationship with another person (Witmer \& Sweeney, 1992).

\section{Life Forces}

Witmer and Sweeney (1992) define life forces as "major societal institutions that impinge on the health and wellbeing of each individual" and include the family, religion, education, community, media, government, and business or industry.

The life force family relates to family relationships, belonging and social support. Family wellbeing is increased through family support and constructive parent-child relationships (Fernandez, 2004).

Religion refers to aspects of social harmony, construction of meaning in life, hope and inner peace, and refers to the acknowledgement of a higher power (Witmer \& Sweeney, 1992).

Witmer and Sweeney (1992) emphasise the impact of education on wellness. Cohen (2006) refers to academic learning, and the development of emotional, social, and ethical competences as contributive to overall wellbeing.

Community is a major life force, impacting on health and wellbeing through social institutions (Witmer \& Sweeney, 1992). It involves a balance between connectedness and independence. When individuals feel a sense of belonging, both individual and community needs are fulfilled.

Media influences individuals' perceptions of needs, beliefs, priorities, norms and values, attitudes and desires (Witmer \& Sweeney, 1992). It can 


\section{Mayer - Holistic Wellness in a Women Leader}

impact positively and constructively, as well as negatively on health and wellbeing (Sweeney \& Witmer, 1991).

Policies and government practices contribute positively and/or negatively to the wellness of an individual (Witmer \& Sweeney, 1992). Governments carry a responsibility for societal and collective health and wellbeing (WHO, 2002).

Finally, businesses or industry, as a major work environment, impacts on health and wellbeing to empower and foster individuals (Mayer, 2011). Health is promoted in organisations on physical, mental, social, psychological and spiritual levels (Mayer, \& Boness, 2011).

Global events impact on the health and wellbeing of individuals. Such global events could include economic exploitation, wars, violation of human rights, unemployment, competition for limited resources, as well as poverty or environmental issues, such as pollution, diseases and overpopulation (Sweeney, 1998). These events are communicated via the mass media and instant communication methods, and impact on the life quality, mental health and wellbeing of individuals (Sweeney, 1991, 1998).

\section{Aim and purpose}

This research aims to satisfy the need for a longitudinal, in-depth single case study on holistic wellness in a selected woman leader in the Engineering profession in an Australian Engineering organization that is a global player in the field. The purpose is to present insights into the concept of holistic wellness according to the holistic wellness model (HWM) (Myers, Sweeney \& Witmer, 2000) from a gender-specific perspective.

The research responds to the questions of how wellness is defined and what contributes positively to the participant's holistic wellness in terms of HWM from an emic perspective to face and manage the challenges of the profession. This study thereby contributes to new in-depth knowledge on the construction of the HWM in a male-dominated profession.

\section{Research Methodology}

The study is based on single case study design (Yin, 2009) which is anchored in the hermeneutical tradition of Dilthey's (2002) modern 
hermeneutics which connects to the descriptive and analytic psychology and focuses on the uniqueness and extraordinary aspects of a person in his/her wholeness (Lock \& Strong, 2010). Additionally, human subjectivity is viewed as being part of the research process and its findings. Understanding is reached when the researcher applies a self-reflective attitude to achieve intra-subjectively validated findings (Dilthey, 2002).

\section{The sample and setting: participant and the organisation}

Purposive sampling was applied to choose $M$ as the subject of research. $M$ is Australian citizen who was born in a capital city in Australia. She attended a private school and completed her schooling at the age of 17. After matriculating, $M$ spent one year on a Rotary exchange programme in Europe, living with 3 different families for four month at a time. She then studied Engineering at University and completed a Bachelor's and Honours degree with specialisation in Civil Engineering. After obtaining her qualifications in 1990, M started working for a company at which she still works in the year 2015. However, M took a long-service leave in 2003 (mainly to travel abroad) and she resigned in 2004, moving to East Africa where she got married to her husband. She returned to Australia with her husband in 2006. She was then offered a job in a government institution, but was headhunted by the Engineering company from which she resigned and instead chose to return to them. From 2006, M worked part-time (15-28 hours per week) and took maternity leave twice. In 2012, M accepted the offer of the organization to work as an Australian expatriate in South Afirca. She stayed with her family in South Africa from 2013 to 2015 when this study took place. At the time of the interview, $M$ was 47 years old, married to her husband who was born and raised in Kenya and who is now Australian citizen. They have two children who are in primary school. M and her husband have lived together in Kenya, Australia and South Africa and have gained strong intercultural competences through their common international work and travel experiences.

The organization $\mathrm{M}$ works for is a global engineering, management and technical service organisation headquartered in Australia. The organisation runs subsidiaries around the world and is a global player that provides services for public and private sector clients. Core values of the organization 


\section{Mayer - Holistic Wellness in a Women Leader}

are excellence, innovation and collaboration, as well as diversity, integrity, honesty and sustainability. ${ }^{2}$

$M$ was chosen for this single case research study because of (a) her leadership position as a women leader in a global, male-dominated engineering organization with headquarters in Australia; (b) her specific interest in socio-economic, health- and faith-related topics; (c) her openness towards the research, and (d) her accessibility during the time of the research.

\section{The entrée into the research field and the researcher-researched relationship}

The researcher met $M$ for the first time in a private context in 2013, while both were working on work-related projects in South Africa. From that time onwards, the researcher and the researched met with their children during leisure time, out of which interesting discussions around work, women leadership, Engineering, social, religious, political and economic discourses evolved.

$\mathrm{M}$ was invited to join the women leader research project an accepted the invitation instantly. Ethical considerations were applied and the researched was informed about the study's purpose, about her rights, confidentiality and the anonymity in the research. The researcher and the researched developed a stable relationship and met for discussions and conversations over weekends. During this time, the researcher observed the development of $\mathrm{M}$ throughout a period of 18 months.

The researcher-researched relationship created an in-depth understanding of the context, the actors, the environment and the interactions in current perspectives and provides insight into both, the construction of sociocultural realities and the research findings (Bryman, Stephens \& Á Campo, 1996). This interaction contributed to the construction of a common reality during the time of research.

\section{Data collection}

Data was collected through conversations, observation, collateral talks and an in-depth interview on the focused research questions on women 
leadership in the Engineering field, mental health, holistic wellness (concepts and emic perspectives), the HWM and faith (the development of faith throughout the life span). Follow-up conversations were held face-toface. Interview questions included, for example, "Which aspects make your life meaningful?", "What creates meaningfulness at work for you?", "What contributes to your wellness at work?", "What is the role of spirituality in your life and at work?"

Based on prior conversations in which many of the aspects of the HWM were addressed, the in-depth interview was conducted to focus on life tasks, life forces and global events (Myers et al., 2000) so as to create a further and deepening understanding of holistic wellness in the selected participant.

\section{Data analysis and reflexivity}

Data were analysed through a 5-step process of content analysis (Terre Blanche et al., 2006, 322-326). Firstly, the researcher familiarised herself with the data and immersed herself into the data sets (Step 1). In the following step, themes were induced (Step 2), categories and codes were constructed (Step 3), data were elaborated (Step 4) and finally, the newly arranged data were interpreted and checked (Step 5).

The interpretation of the data and the checking was supported by a selfreflexive research approach (McLoed, 2003), a critical reflection of the research bias, the subjectivity of the researcher, and the self-positioning of the researcher and the researched (Mruck \& Breuer, 2003) and their relationship (Wang, 2012). The strong focus on the researcher's selfreflexivity led to intra-subjective validation processes on the researcher (Yin, 2009) regarding the data, the analysis, the findings, the development of the researcher and the researched, and their interactions and relationship development. Intra-subjective validation (Van Kaam, 1966) was carried out through reflexivity and through the exploration of various subjective perspectives the researcher has of the topic. The reflexivity supported the construction of the "hermeneutical circle" (Dielthey, 2002) which includes entering into the field, working through the data and understanding the other, reworking the purpose and aims of the study, rendering of parts of the study into a whole, and the reimagining of study elements (Shotter, 1981). 


\section{Mayer - Holistic Wellness in a Women Leader}

\section{Quality criteria for content analysis in case study research}

Kohlbacher (2006) points out important qualitative quality criteria, such as openness and the ability to deal with complexity in research, which uses a holistic perspective. Such criteria use theory-guided analysis, the integration of the context and the integration of different material and evidence such as interviews and observations. Mayring (2000) mentions that qualitative content analysis should be theory-guided in terms of the analysis and interpretation. Mayring's approach (2000) was practiced in this research. These quality criteria were addressed throughout the research.

\section{Considerations and limitations}

This study is a single case study and explores the in-depth subjective experiences, thoughts and feelings of a single person. The findings reflect the process of research between the researcher and the researched and the process of interpretation is viewed as reflecting the researcher-researched relationship and the interactive process of interpretation and intra-subjective validation processes based on pre-understandings of concepts (Dilthey, 2002; Ricoeur, 1981) and the "hermeneutical cirlcle" (Dilthey, 2002). The study is limited in terms of the time frame of this research which was only 18 months long. The participant's selection process was purposive, but included only four criteria and is therefore limited. Finally, the study does not claim any intent to offer a generalized result, but rather delineates an indication of the subjective experience of mental health and its interlinkages with the HWM based on the study and reflections of the researcher and the researched.

\section{Research findings, interpretation and discussion}

In the following section, the findings on the participant's emic perspective on holistic wellness and its impact on her life, work and leadership, as well as on the management of challenges faced in her profession, are presented by integrating description, analysis and interpretation of findings. The findings are also reflected in the context of the theoretical HWM. 


\section{Defining wellness}

For M, health and wellness are topics that are in her focus and scope of daily life. She emphasises that wellness is:

An absence of stress, having my mood swings under control, a sense of peacefulness, less weight that I am carrying at the moment, being able to sleep, the ability to switch off, not having a disease.

M states during the interview that she is "not well at the moment", because she does not feel peaceful, struggles to switch off and would like to lose weight. Her wellness concept refers to physical, emotional and psychological aspects and uses a holistic concept, as in Myers (2009). Wellness is generally an important topic for $\mathrm{M}$ and has gained interest for her personally, as well as in the leadership and organisational psychology literature (Mayer \& Van Zyl, 2013).

In Myers (2009) and Myers, Sweeney and Witmer (2000), wellness is defined positively, referring to life-orientation, and body, mind and spirit integration. $\mathrm{M}$ also defines wellness with regard to positive constructs, such as peacefulness, abilities to switch off and sleep. M does not, however, only employ a positive psychology definition with regard to optimal functioning, self-responsibility and motivation (Roscoe, 2009), but also includes demarcations with regard to the absence of disease, mood swings and stress. $\mathrm{M}$ refers to a holistic wellness approach, mentioning physical, spiritual and psychological aspects which contribute to her wellness. Referring to holistic wellness, M highlights various aspects that contribute to her wellness which are described, analysed and interpreted in the following. They are then integrated with regard to the HWM and refer to family and career, facets of self-direction, spirituality, love, friendships and her personal worldview.

\section{Professional drivers in work and leisure: family and career}

$M$ identifies two professional drivers that persuaded her to work in her first chosen profession - Engineering - namely family and career. 
My two primary orientations would be family and career and I just took a while to find out which order I would put them in and, I think that is the right order. I actually gave up my job in order to have a family. That was very important to me and then having achieved that, I am now back in the career and I am interested in contributing to that career in a substantial way... people could say that I just sort of work in this job because of... for my kids and unfortunately it's the thing, but sometimes I struggle with it. I really do find that a problem... but why am I spending my energy on something that I don't in my real core believe in... that's what I believe in is transformation of the organisation so that people have more abilities in the community and what I am doing in working for a mining company and consulting the mining companies... could I be consulting the mining company and they would... now being forced to do a lot more in the community.

M works in the organisation to provide her children with a high level of education and a high living standard and to have leisure time to spend with her family, an activity which she enjoys most:

So being able to just be with my family, go for walks, sit on the grass, being connected with family... being able to waste time with them, so that's the true meaningfulness... so that is number one. And two so that in terms of the career aspect... in the business trying to change culture, trying to create understandings of different ways of approaching things and finding people who are ready to go on a journey mentoring that. That's what actually excites me the most.

$\mathrm{M}$ uses her profession to maintain her family's high living standard, although her personal values do not completely match the work and ethical values of the organization. She visualizes transforming the organization towards a more social and community orientated organization which is founded in concepts of social responsibility and social justice. As such, she emphasises the need to change the organization's business culture so as to create understanding and define new ways of approaching business. 
The findings show that $\mathrm{M}$ strongly values the life force of family, to the extent that she even works in Engineering, a field to which she is not totally loyal. The life force "family" has the highest priority for her, creating meaningfulness in the context of the life tasks work and leisure.

Work is important for M. She uses work to self-actualize, to express her values, to contribute to social responsibility and justice, to keep her living standard and to provide a financial base for her family. Work, however, only partly provides a "sense of accomplishment and pleasure" (Myers at al., 2000, pp. 256) and is partially meaningful for her and for others (Mayer, Surtee \& May, 2015). This is due to the fact that $M$ does not comply completely with the values of the organization.

For M, work provides particular economic benefits, as well as a few psychological (generally being able to work) and social benefits (work with colleagues and mentoring) which contribute to her holistic wellness (Witmer \& Sweeney, 1992). However, the fact that her personal values are hardly reflected in her work context, leads to a value discrepancy that affects M's holistic wellness negatively by impacting on her stress levels. This might be connected to her self-perceived feeling of "not being well at the moment". The life force "community" (Witmer \& Sweeney, 1992) stays mainly unfulfilled due to the fact that $M$ perceives an imbalance between the fulfilment of her personal and the community needs which are affected by her Engineering work. While M feels psychologically rather connected to and responsible for the communities which have to compromise due to Engineering organizations and their operations, $\mathrm{M}$ depends on her job as she is the breadwinner in the family and enjoys her career path at the same time. However, she struggles with the fact that she works for an organization that does not prioritise global justice and social responsibility towards the communities in which they work.

This discrepancy in values between M's association with a community of global Engineers on the one hand, and her emotional connection with the communities being treated irresponsible and unjustly by that community of Engineers on the other, impacts negatively on M 's holistic wellness, since individual and social needs and values are not fully adjusted in terms of community belonging. 


\title{
1111 Mayer - Holistic Wellness in a Women Leader
}

\section{Professional driver: facets of self-direction}

M's vision is to transform the Engineering mining organization into a more community-orientated organisation which benefits individuals and communities. It is this vision that keeps her in her position and the organisation. Besides being concerned about the gap between the company's values and her life orientations, her personal values and visions, $M$ is also critical about her remuneration and other aspects of her job:

\begin{abstract}
I find that what I do is at total odds and the amount of money that I get for what I do is totally disproportionate. There are a lot of things that I do in my work, if I think too much about it I get sad for my personal values. I just have to say: Well, I am back in the business, because I now have kids and want the comfort of that... ideal what you call it [laughing]... the other aspect that I am just totally at odds with in my position as an engineering consultant is the whole sense of lack of global justice. It is a very strong drive for me, but I don't at the moment actually focus on that.
\end{abstract}

$\mathrm{M}$ is very self-reflected and clear about her self-direction: she knows her values, her direction and long-term orientation towards her family and global justice. She is realistic in her beliefs - having to compromise on her personal values in her profession for the sake of her family and her living standard and at the same time seeing the potential for transformation in her work. However, she is also aware of her ability to control parts of what is happening in the organizational and professional field. $\mathrm{R}$ knows she could start transforming the organization towards a more socially and globally just environment and she knows she could impact and make a difference in her organisation. Furthermore, $\mathrm{M}$ is emotionally and cognitively aware of her value dilemma and copes with it by prioritising the fulfilment of her individual (and family) needs. She is also aware of her worth as a person and her possible influences on transformation within her organization. However, she does not recognise and acknowledge the worth of her work in the context of her remuneration which she judges as "disproportionate". In a sense, $\mathrm{M}$ does not care about herself at the time of the interview, because she does not follow her personal values, but rather sacrifices them for the sake of 
her family and partly for the sake of her career in the Engineering environment.

Since, at this moment in M's life, her family is her priority, $\mathrm{M}$ is not able to implement her values of transformation in the organisation. However, she implements other values which are important to her. For M, drivers at work are, for example, inspiring people within the company, motivating them and networking:

The thing that is most easily recognised and has value within my company, is having great connections and networks and getting people in the company to really work with clients and I am not a client-orientated person. I can do it, but it is not what drives me. What I really enjoy is actually inspiring people inside the company, the function in networking and getting people motivated - sometimes it's a full-time job [laughing].

These aspects of networking and inspiring others are strongly interwoven with self-direction in terms of problem-solving and creativity (Myers et al., 2000) and contribute to M's job satisfaction, her personal motivation, her drivers at work and therefore her holistic wellness. However, she feels that her personal drivers clash or are at least in conflict with the highly regarded company values, such as networking and building connections with clients. This discrepancy between her personal drivers and interests (developing and mentoring employees) and the company's values (networking with clients) might impact on $\mathrm{M}$ 's holistic wellness in the work context as well. This experienced gap between personal motivations and interests - and the organisational mindset referring to the life force of business and industry (Witmer \& Sweeney, 1992; Myers et al., 2000) - leads to other aspects which $\mathrm{M}$ is critical about.

Finally, two other aspects which are sub-tasks of self-direction are gender and cultural identity-related and they impact on M's holistic wellness with regard to the Engineering work context:

I think it's gender and personality profiles that influence engineering typically. The stereotypic engineer is an introvert, analytical person whereas my personality is extrovert analytical and strategic analytical not entire analytical. I suppose being on 


\section{Mayer - Holistic Wellness in a Women Leader}

the gender side both the stereotypical and born a communicator as a woman that all happened to interest me in quite a different person in the majority of people in my work.

$M$ feels that she is not a stereotypical engineer and therefore defines herself not as being part of the typical engineering community, but rather as someone outstanding in terms of her gender (as a woman in a maledominated profession), and also as a person with an extrovert analytical and strategical analytical profile. In other words, she describes herself as belonging to a minority group within the majority of typical engineers, on two levels. She uses the majority of the Engineering community as an alternative model to her gender and cultural identity description. She does see her gender as a challenge in the male-dominated profession but, at the same time, uses this outstanding characteristic as a positive force to define herself in terms of identity. This behaviour is consistent with descriptions in the literature (Kinnear, 2014; Rudman \& Phelan, 2010; Sandberg, 2013; Toh \& Leonardelli, 2012).

Focusing further on her gender identity in terms of self-description and expectations, $\mathrm{M}$ emphasises:

I don't tend to take that mothering role. I suppose that is consistent with me not wanting to be stereotypical, so there will be people within my profession that will say that you should be career-orientated and focused, because they might measure me in terms of what they expect a woman to do. Not in terms of what I am... I think I have ended up come to terms with the fact that I am a person who continues to put myself in positions where I am... against [laughing].

In terms of self-direction, $\mathrm{M}$ is aware of the expectations of her environment and describes them as differentiated. $M$ points out that her colleagues might measure her in terms of their stereotypes and expectations of women - as highlighted by Du Plessis and Barkhuizen (2012). However, these expectations do not seem to impact negatively on $M$ 's resilience (see Martin and Barnard, 2013 and Van Wyk, 2012), as she seems to turn these expectations down instead by acting "against". M even seems to draw positive energy from "swimming against the mainstream current" and 
leaving stereotypical expectations unfulfilled. This does not seem to contribute negatively to her resilience, but rather provides her with energy to do her work differently and to make a difference.

$\mathrm{M}$ acknowledges (self-direction subtask: emotional awareness and coping) her extraordinary identity and of "who she is" (self-direction subtask: gender and cultural identity). $M$ sees herself as a person who does not define herself as a core of the communities in which she is integrated. She instead sees herself as a person with an identity who is critical and who chooses alternative behaviours, thoughts and actions. This self-definition in terms of gender and cultural identity contributes to her holistic wellness in that it enables her to make a difference by evoking and increasing selfreflection and discussion.

\section{Spirituality in the workplace and love at home}

$\mathrm{M}$ is a highly spiritual and faith-based person. She grew up in a religious family that adhered to the Christian faith and started her personal spiritual journey while in her twenties. Generally, M comments that the life task spirituality has more space within the life force business and industry in the South African than in the Australian work context. This makes her feel more relaxed in her expatriate work field and provides her with an increased sense of wholeness than does her Australian work context:

Spirituality has a lot more space in the South African context than it does in the Australian context... even in the Australian context that whole idea of social responsibility is coming in... more sort of a spiritual base at work... but I find this very conflicting, because what I do is providing people possibilities to develop which contribute to those... leaving the country because there is more opportunities for them.

$M$ perceives the professional workplace during the time of her expatriation as more spiritual than her Australian workplace. In her Australian work context, and due to her family of origin, particularly her mother, she perceives spirituality as being related to the application of concepts of social responsibility. From M's point of view and in the way that spirituality is related to social responsibility, $\mathrm{M}$ is in a conflict with herself, 


\section{Mayer - Holistic Wellness in a Women Leader}

because she feels that by doing her job and developing individuals, she contributes to their opportunities on the one hand and to them leaving the country on the other. For her, this impact of her work does not necessarily comply with her spiritual values as these relate to social responsibility. $\mathrm{M}$ has high regard for spirituality. This impacts strongly on her, particularly with regard to her private life. M comments that her husband's influence on her spiritual wellbeing is strong and that her spirituality is strongly influenced by her love relationship with him (life task: love). Spirituality, as a core of the life-tasks of holistic wellness, impacts on $\mathrm{M}$ and her personal drivers. However, the findings do not show that spirituality is the strongest core of her holistic wellness.

The life tasks spirituality and love are interconnected for $\mathrm{M}$ and impact positively on $\mathrm{M}$ 's holistic wellness:

Certainly now my husband is very grounding... so the whole issue of staying emotionally well and spiritually centred in many respects... because he doesn't provide support when I am in a bad mood and that actually encourage me to get out of that my silly space.

For M, spirituality is based in her home and private environment and relationships rather than at work. At work, the concept of spirituality is related to social responsibility and justice (life force: business and industry) whilst at home it is based in the context of the life task of love and the life forces of family and community. This shows that holistic wellness is very much interconnected in terms of various life tasks and life forces. This finding also shows the varying foci and drivers of $\mathrm{M}$ at work and at home.

\section{Relationships as health-related stabilising factors}

Another highly important life task that plays a positive role in terms of holistic wellness is friendship. M explains:

Friends are really important to me and not as important to my husband and so that's actually a source of conflict... difference in spending energy in that I need to be social and he doesn't have that need... I have a friend in Brisbane and we haven't 
contacted each other in two years and then I go back to Brisbane I am going to have coffee with her... I think you can get to the friends you need where you are at the time and those people play that role... I don't have a large group of friends,... not more than two or three.

$M$ sees friendships as important with regard to living in the present moment. She prefers having a few trusted friends instead of a large group of friends and living her friendships in the present moment in which she lives. $M$ trusts in finding the right friends at the right time and believes this contribute to a person's development. Friendships do not necessarily need to be close or kept over long distances.

\section{World view}

Finally, M comments on her world view, on her general orientation in life and on her connection to global events.

I don't watch daily news very often. It can be once a month I don't read news on the Internet, so I don't get impacted by event by event, because I don't think that it a very healthy way of looking at the world. My worldview, it sort of comes through osmosis, sharing ideas with friends that you meet and [laughing] sharing how much do I worry about with global future. From time to time it impacts on me and particular in sort of trying to work out with what type of people you are and you want your children to be with... that impacts... I do not stress too much about the global future.

$\mathrm{M}$ feels that not being informed of each and every current global event is healthier than being too involved in and worrying about such things. $M$ finds it more important to focus on the present moment, her life and her children than on global events, the news and the global future as these do not impact on her directly in the present moment. $\mathrm{M}$ is anchored in the present moment and her local life environment. This contributes towards her holistic wellness. Although $\mathrm{M}$ discusses global events with friends from time to time, her focus is on her immediate environment and local concerns, because she feels that she can impact her local environment, but not global concerns. 


\section{Mayer - Holistic Wellness in a Women Leader}

\section{Physical wellness}

During the time of the interviews and conversations, $M$ does not feel entirely well. However, she has started to "fix her wellness" with regard to "nutrients and herbal remedies and what not to try". Besides the change in nutrition, she has signed up at a gym, but does not make time to go there. M feels selfresponsible for her wellness, while being strongly supported by her husband. Together, they focus on healthy nutrition and exercise, with her husband supporting her emotionally as well through his encouragement "to get out of that silly space" she is in. M 's husband builds an important emotional and spiritual base within the family and thereby provides $M$ with the possibility to combine family and career.

\section{Conclusion}

This research aimed to satisfy the need for a longitudinal, in-depth single case study on holistic wellness in a selected women leader in the Engineering profession. The purpose was to present insights into the concept of the HWM (Myers, Sweeney \& Witmer, 2000) with regard to a woman leader in the male-dominated Engineering context.

The research responded to questions of how wellness is defined and what contributes positively to the participant's HWM from an emic perspective which enables her to face and manage the challenges of the profession. This study thereby contributes to new in-depth knowledge on the construction of holistic wellness in a male-dominated profession.

Findings show that $\mathrm{M}$ uses a holistic wellness concept that integrates aspects of positive psychology as well as references to negative wellness (illhealth), as the absence of disease and stress.

Referring to holistic wellness as a woman leader in the Australian and global male-dominated Engineering profession, $M$ refers to certain aspects that contribute to and impact on her holistic wellness (see Figure 1), such as her family, her career, various aspects of self-direction, (including sense of control, realistic beliefs, sense of worth, emotional awareness and coping, self-care, gender and cultural identity), spirituality, love, friendship, and her personal world view. M does not highlight all of the life forces addressed in 
the HWM: she does not comment on education, media and government policies as impacting on her long-term and sustainable holistic wellness.

Figure 1

The HWM in a woman leader in Engineering

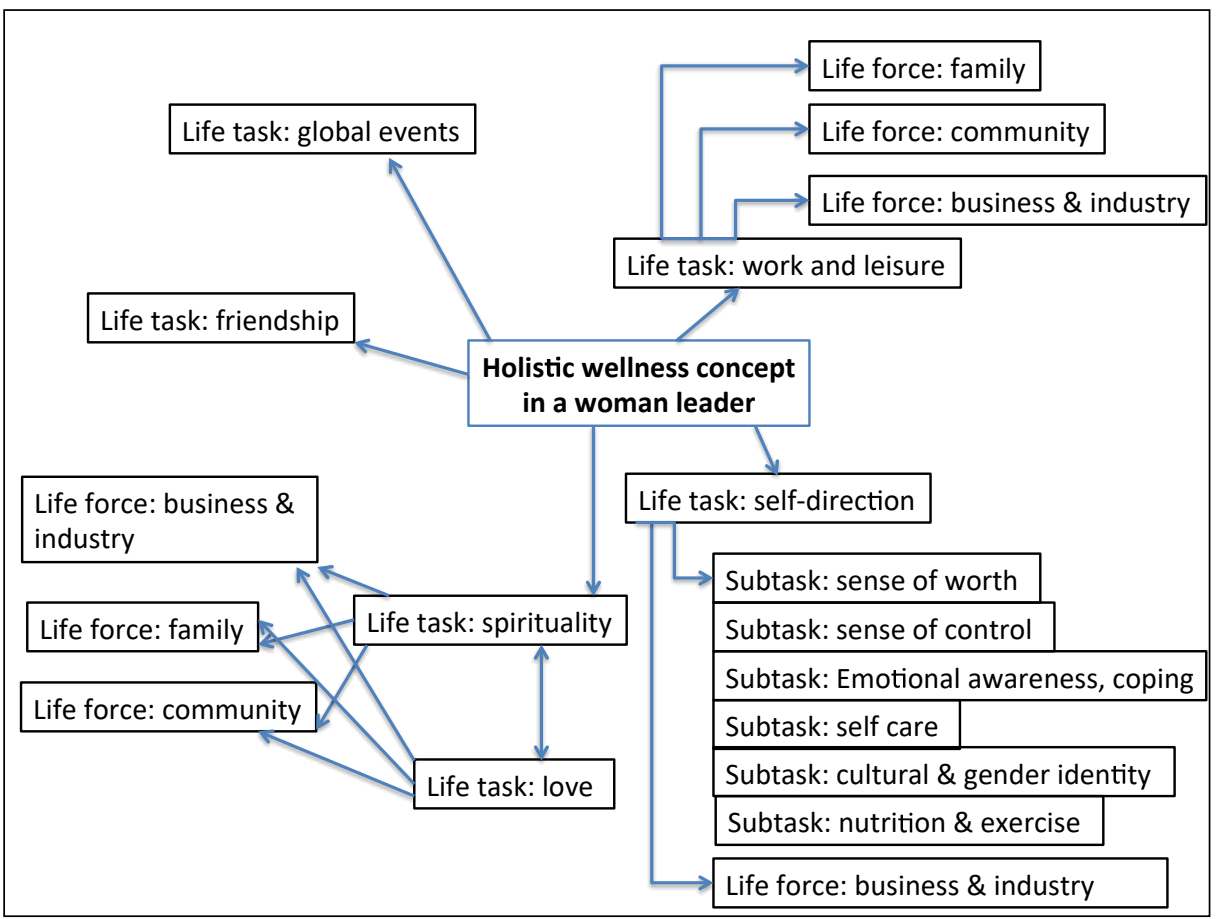

In terms of life tasks, work and leisure, self-direction, spirituality and friendship are exceptionally important to address challenges and manage holistic wellness in M's Engineering profession.

In the context of work and leisure, the life forces family and business and industry are prioritised and ranked. The life force community is important in terms of values, but is not addressed actively at the moment which might impact negatively on the holistic wellness.

The life task self-direction is strongly important for keeping and promoting M's holistic wellness through the subtasks of worth of self ( $M$ is 
aware of her worth), sense of control (she is conscious about her possible impact on transformation and values), emotional awareness and coping ( $M$ is aware of her feelings, her priorities and the choices she makes in life), cultural and gender identity ( $\mathrm{M}$ is aware of her gender, its impact on her work and life as a woman leader in Engineering) and her cultural and personal identity. She is also conscious of her nutrition and level of exercise in terms of her self-direction and her self-care. She knows that she could increase a bit of her self-care aspect by exercising more and that she could increasing her sense of control by implementing her visions of transforming the organization.

$\mathrm{M}$ further acknowledges the importance of spirituality (in terms of social responsibility and global justice) and love (with regard to her husband and his impact in her life), as two major life tasks which impact positively on her holistic wellness. She also recognises the connection of spirituality and love in her life and the interrelationship with the life forces of family, community and business and industry.

Finally, M keeps well thanks to her friendships and thanks to her worldview that does not include too much information that would increase her concern for global events. Her wellness derives instead from her focus on the present moment in the local environment she lives in.

In conclusion, M's HWM impacts on her ability to be a strong women leader in the global Engineering field, an expatriate and a shareholder of a company, while being a mother of two and a wife. The study shows that several holistic wellness aspects impact positively on M's strength at mentoring colleagues in the global Engineering profession while running international projects successfully.

Further on, M could increase her holistic wellness by increasing her selfdirection in terms of an increased self-care and sense of worth, not only with regard to herself, but also with regard to the work she does. Through implementing her vision and an increased creative, problem-solving approach, M could surely increase her holistic wellness by matching her personal values with that of the company. This could happen through implementing her values more strongly into her work field and by transforming her company into a more socially responsible, globally just and community-orientated organization. The implementation of this vision into 
her daily work life and routine would probably increase her holistic wellness as a woman leader in Engineering even more.

\section{Recommendations for theory and practice}

This study shows the importance of holistic wellness to the woman leader researched in this long-term study. Holistic wellness connects various work, career and family related issues with regard to leaders and employees within organizations.

Future research should focus on exploring holistic wellness in leaders in male dominated occupations and compare those holistic wellness concepts of men and women in leadership position in the Engineering work environment. Multi-method studies should integrate qualitative and quantitative research findings and thereby provide a holistic view of wellness from qualitative and quantitative perspectives through various methodological research lenses to, in the end, come to holistic conclusions on holistic wellness and its construction in women leaders working in maledominated professions.

This and future research should lead to practical implications for organizations in the Engineering field. This study provides in-depth knowledge on the need for woman leaders to integrate personal, workrelated and organizational values. To become an attractive employer on the macro level for highly qualified women leaders, the Engineering organizations should focus on organizational values, such as social and global justice, responsibility, as well as sustainability. On the meso (organisational) level, Engineering organisations should focus on gender equality, women leadership, career development and the promotion of individual, career and family management for women leaders, as well as on the integration of personal leadership preferences and values in congruence with the global and the organizational culture. Furthermore, to be attractive to highly qualified women leaders, the organization's approach to Engineering should be socially responsible, eco-friendly and communitybased. Engineering organizations need to develop an organisational culture that becomes family friendly, sustainable and that provides areas of development for careers of women leaders, as well as new and alternative 


\section{Mayer - Holistic Wellness in a Women Leader}

approaches of global Engineering with local, communal and ecologically sustainable responsibility.

\section{Acknowledgements}

I wish to express my sincere thanks to $\mathrm{M}$ for her willingness to be part of this research project and for her insightful contributions.

\section{Notes}

${ }^{1}$ For an in-depth overview on definitions of life tasks, life forces and global events see Witmer and Sweeney (1992) or Myers et al. (2000).

${ }^{2}$ According to the organizational website which is not mentioned due to confidentiality.

\section{References}

Bagilhoe, B and White, K. (2011). Gender, power and management: A Cross-Cultural Analysis of Higher Education, Palgrave Macmillan, London.

Bryman, A, Stephens, M and Campo, C. (1996). The importance of context: Qualitative research and the study of leadership, Leadership Quarterly, 7(3), 353-370.

Carli, LL, and Eagly, AH (1999) Gender effects on influence and emergent leadership, in G.N. Powell (ed.), Handbook of gender and work,Thousand Oaks, CA: Sage, pp. 203-222.

Coetzee, S and Viviers, R. (2007). An overview of research on positive psychology in South Africa. South African Journal of Psychology, 37(3), 470-490.

Cohen, J. (2006). Social, emotional, ethical, and academic education: creating a climate for learning, participation in democracy, and wellbeing. Harvard educational review, 76(2), 201-237.

Dilthey, W. (2002). The formation of the historical world in the human sciences, Wilhelm Dilthey selected works, Volume III, Princeton University Press, Princeton.

Du Plessis, Y and Barkhuizen, N. (2012). Career path barriers experienced by women engineers. Paper presented at the 12th European Academy of Management Conference, Rotterdam, Netherlands. Retrieved from http://www.optentia.co.za/publications.php 
Eagly, AH. (2007) Female leadership advantage and disadvantage: resolving the contradictions. Psychology of Women Quarterly, 31, 1-12.

Fernandez, E. (2004). 'Effective interventions to promote child and family wellness: a study of outcomes of intervention through Children's family centers', Child \& family social work, 9(1), 91-104.

Gouws, A. (2008). Obstacles for women in leadership positions: A case of South Africa', SIGNS: Journal of Women in Culture and Society, 34(1), 21-27. doi: org/10.1086/588486

Kinnear, L. (2014). A critical analysis of the emerging models of power amongst South African women business leaders. [Unpublished doctoral thesis] University of KwaZulu Natal, Kwa Zulu Natal, South Africa.

Kohlbacher, F (2006). The use of qualitative content analysis in case study research. Forum: Qualitative social research, 7(1), Retrieved from: http://www.qualitativeresearch.net/index.php/fqs/article/view/75/153\#g52

Lock, A and Strong, T. (2010) Social Constructionism. Sources and Stirrings in Theory and Practice, Cambridge University Press, Cambridge, UK.

McLeod, J. (2003). An introduction to counseling. Open University Press, Philadelphia.

Martin, P and Barnard, A. (2013) The experience of women in maledominated occupations: A constructivist grounded theory inquiry. South African Journal of Industrial Psychology, 39(2). doi:org/10.4102/sajip. v39i2.1099

Mayer, C-H. (2011). The sense of coherence in transcultural management, Waxmann, Münster.

Mayer, C-H and Boness, C. (2011). Concepts of health and well-being in managers: An organizational study. International Journal of Qualitative Studies on Health and Well-being. 6. doi:10.3402/qhw.v6i4.7143.

Mayer, C-H and Krause, C. (2013). Salutogenese in Beratung und Psychotherapie, in C-H. Mayer, C Krause (eds.), Praxis Klinische Verhaltensmedizin und Rehabilitation, 26(2), pp. 91-178.

Mayer, C-H and Viviers, A. (2014). '"I still believe..." Reconstructing spirituality, culture and mental health across cultural divides', C-H Mayer and D Geldenhuys (eds.), Spirituality, culture and health in management. Special Issue International Review of Psychiatry, 26(3), 265-278. 
Mayer, C-H, Surtee, S and May, M. (2015). 'The meaning of work for women across cultures. Insights into women working in higher education institutions', South African Journal of Higher Education.

Mayring, P. (2000). 'Qualitative Inhaltsanalyse', in U. Flick, E. von Kardorff and I. Steinke (eds.), Qualitative Forschung, Ein Handbuch

Rowohlt,Reinbeck bei Hamburg, 468-475.

Mruck, K and Breuer, F. (2003) 'Subjectivity and reflexivity in qualitative research - The FQS issues', Forum: Qualitative Social Research, vol. 4(2), http://www.qualitativeresearch.net/index.php/fqs/article/view/696/1504

Myers, JE. (2009) 'Wellness through social interest: The goal of helping', in TJ Sweeney (ed.) Adlerian counselling and psychotherapy: A practitioner's approach, ( $\left.5^{\text {th }} \mathrm{ed}\right)$, Routledge. New York, NY, 33-44.

Myers, JE and Sweeney, TJ. (2007). 'Wellness in counseling: an overview. Professional Counseling Digest', ACAPCD-09, American Counseling Association, Alexandria, VA.

Myers, JE and Sweeney, TJ. (2008). 'Wellness counseling: The evidence base for practice', Journal of Counseling and Development, 86(4), 482 493. doi:10.1002/j.1556-6678.2008.tb00536.x

Myers, JE, Sweeney, TJ and Witmer JM. (2000). 'The wheel of wellness counselling for wellness: A holistic model for treatment planning', Journal of Counseling and Development, 78(3), 251 - 266. doi:10.1002/j.1556-6676.2000.tb01906.x

Ricoeur, P. (1981). Paul Ricoeur, hermeneutics and the human sciences: Essays on language, action and interpretation, Cambridge University Press, Cambridge, UK.

Roscoe, LJ. (2009) 'Wellness: A review of theory and measurement for counselors', Journal of Counseling and Development, 87(2), 216 - 226. doi:10.1002/j.1556-6678.2009.tb00570.x

Rudman, LA and Phelan, JE. (2010) 'The effect of priming gender roles on women's implicit gender beliefs and career aspirations', Social Psychology, vol. 41(3), 192-202. doi: 10.1027/1864-9335/a000027 Sandberg, S. (2013) Lean in: Women, work and the will to lead, Random House, Lean In Foundation, NY.

Sharp, R, Franzway, S, Mills, J and Gill, J. (2012). 'Flawed policy, failed politics? Challenging the sexual politics of managing diversity in 
Engineering Organizations', Gender, work \& organization, 19(6), 555572.

Shotter, J. (1981) 'Vico, moral worlds, accountability and personhood', in PLF Heelas and AJ Lock (eds.), Indigenous Psychologies: The Anthropology of the Self, Academic, Press, London, 265-284. Strümpfer, DJW. (2005) 'Standing on the shoulders of giants: notes on early positive psychology (psychofortology)', South African Journal of Psychology, 35, 21-35.

Sweeney, TJ. (1998). Adlerian Counseling: A practitioner's approach, Taylor and Francis, New York.

Sweeney, TJ and Witmer, JM. (1991). Beyond social interest: Striving toward optimum health and wellness, Individual Psychology, 47(4), 527 -540 .

Temane, QM and Wissing, MP. (2006) 'The role of spirituality as a mediator for psychological wellbeing across different contexts', South African Journal of Psychology, 36(3), 582-597.

Toh, SM and Leonardelli, GJ. (2012) 'Cultural constraints on the emergence of women as leaders', Journal of World Business, 47(4), 604-611.

Terre Blanche, M, Durrheim, K and Kelly, K. (2006). 'First steps in qualitative data analysis', in M Terre Blanche, K Durrheim and D. Painter (eds.), Research in practice. Applied methods for the social sciences, University of Cape Town, Cape Town, 321-344.

Van Kaam, A. (1966) Existential Foundations of Psychology, University Press of America, New York.

Van Wyk, M. (2012). Women leaders, personal leadership and challenges. [Unpublished master's dissertation] University of Johannesburg, Johannesburg.

Wang, X. (2012). The construction of researcher-researched relationships in school ethnography: doing research, participating in the field and reflecting on ethical dilemmas. International Journal of Qualitative Studies in Education, 26(7), 763-779.

WHO (2002). The world health report 2002. Reducing risks, promoting healthy life. World Health Organisation, Geneva, Switzerland.

Witmer, JM and Sweeney, TJ. (1992) A holistic model for wellness and prevention over the life span, Journal of Counseling and Development , 7l(2), 140 -148. doi:10.1002/j.1556-6676.1992.tb02189.x 
1125 Mayer - Holistic Wellness in a Women Leader

Witmer, JM, Sweeney, TJ and Myers, JE. (1998) The wheel of wellness, Greensboro, NC: Author.

Yin, RK. (2009). Case study research. Design and Methods. Fourth edition, Sage, Thousand Oaks, CA.

\section{Claude-Hélène Mayer}

Department of Management, Rhodes University, Grahamstown, South Africa.

Lehrstuhl Sprachgebrauch und therapeutische Kommunikation, Kulturwissenschaftliche Fakultät, Europa-Universität Viadrina, Frankfurt (Oder); Germany.

Contact address: Department of Management, Box 94, Grahamstown 6140, South Africa.

E-mail address: claudemayer@gmx.net 